\title{
Analisis Model Multiple Regression untuk Prediksi Nilai Kurs Rupiah Terhadap Dolar Amerika Berdasarkan Studi Makroekonomi
}

\author{
Wresni Anggraini ${ }^{1}$, Taufiq Irwinsyah ${ }^{2}$ \\ Industrial Engineering Department, Faculty of Science \& Technology, UIN SUSKA Riau \\ Jl. HR. Soebrantas No. 155 Pekanbaru, Indonesia \\ e-mail: wresni_anggraini@ymail.com
}

\begin{abstract}
ABSTRAK
Upaya indonesia untuk meningkatkan sektor industri terganjal dengan bahan baku, dimana 64\% bahan baku diperoleh secara impor. Hal ini merugikan pelaku industri yang dalam transaksi impor menggunakan dolar. Untuk menghindari kerugian tersebut dibuatlah model untuk memprediksi nilai kurs pada periode berikutnya untuk menentukan waktu yang tepat untuk membeli bahan baku menggunakan model multiple regression dengan basis data Oktober 2015 sampai Juli 2016. Variabel inflasi, suku bunga, ekspor, impor dan pendapatan negara digunakan sebagai input untuk membangun model multiple regression. Dari input tersebut didapatkan model $\mathrm{y}=\mathrm{Y}=10.069,111+252,064 \mathrm{x}$ Inflasi $+571,387 \mathrm{x}$ Suku Bunga - 0,140 x Ekspor $-0,059$ $\mathrm{x}$ Impor + 0,002 x Pendapatan Negara dengan nilai MAD 66,96 dan MAPE 0,005. Dari model tersebut pada bulan agustus didapatkan nilai Rp 13.382,07 per 1 US\$, bulan september sebesar Rp 13.228,97 dan bulan oktober sebesar Rp 13.410,94 per 1 US\$. Diharapkan hasil penelitian ini dapat bermanfaat bagi pelaku industri yang mendapatkan bahan baku dengan impor.
\end{abstract}

Kata kunci: dolar, kurs rupiah, makroekonomi, regresi linear

\section{Pendahuluan}

Negara berkembang dengan sumber daya alam yang melimpah, Indonesia seharusnya bisa memasok bahan baku untuk keperluan industri. Tetapi pada kenyataannya porsi impor untuk bahan baku, bahan penolong, dan barang modal menyentuh angka 64\% (kemenperin.go.id, 2014) dari total keseluruhan impor pada tahun 2015 sebesar US\$142 milyar (bps.go.id, 2016).

Banyaknya porsi impor bahan baku dapat merugikan pelaku industri yang dalam transaksi impor menggunakan dolar dimana nilai dolar berfluktuasi secara dinamis terhadap rupiah. Hal ini bisa disebabkan pelaku industri melakukan impor pada saat dolar menguat yang dapat meningkatkan ongkos produksi yang secara otomatis dapat mempengaruhi harga produk. sehingga laba bersih ketiganya turun rata-rata $22 \%$ di periode yang sama (Kemenperin.go.id, 2013).

Kasus lain terjadi pada PT PLN (Persero) yang mengalami rugi bersih $\mathrm{Rp} 10,5$ triliun pada semester pertama 2015. Kerugian paling utama dikarenakan selisih kurs Rp 16,9 triliun. Nilai ini turun drastis dibandingkan laba kurs Rp 4,4 triliun pada semester pertama 2014 (Pln.co.id, 2015).
Ketika harga naik, maka daya beli masyarakat berkurang dan masyarakat cenderung memilih produk alternatif. Jika hasil penjualan tidak dapat menutupi ongkos produksi, perusahaan akan mengalami kerugian.

Contoh kasus yang diakibatkan fluktuasi kurs terjadi pada pelaku bisnis pakan ternak. Berdasarkan riset IFT (Indonesia Food Technologist) dari laporan keuangan tiga emiten (perusahaan yang menjual efek (saham atau obligasi) pada publik) pakan ternak, yakni PT Charoen Pokphand Indonesia Tbk (CPIN), PT Japfa Comfeed Indonesia Tbk (JPFA), dan PT Malindo Feedmill Tbk (MAIN), mencatat kenaikan rugi kurs yang signifikan, rata-rata hampir 10 kali lipat, sepanjang 2013 secara tahunan. Kenaikan Rugi Kurs menekan laba bersih ketiga emiten pakan ternak tersebut

Untuk itu penelitian ini dibuat sebagai suatu instrumen untuk dapat memprediksi nilai kurs rupiah pada periode yang akan datang. Penelitian ini menggunakan metode multiple regression. Metode ini digunakan karena pada dasarnya nilai kurs dipengaruhi oleh banyak faktor, diantaranya seperti inflasi, suku bunga, ekspor, impor dan 
pendapatan negara. Faktor lain yang juga sangat berpengaruh adalah kebijakan politik dan ekonomi, kondisi keamanan, pergantian pimpinan negara atau masuknya orang berpengaruh dalam struktur pemerintahan bahkan juga disebabkan oleh faktor kondisi dan kebijakan ekonomi negara lain (Hady, 2004)

\section{Rumusan Masalah}

Berdasarkan uraian yang telah dijelaskan pada latar belakang masalah di atas, maka masalah dalam penelitian ini dapat dirumuskan "Bagaimanakah Model Multiple Regression untuk Memprediksi Nilai Kurs Rupiah (Indonesia) Terhadap Dolar (Amerika) Berdasarkan Studi Makroekonomi?"

\section{Tujuan}

Adapun tujuan dari penelitian ini adalah sebagai berikut:

1. Untuk mendapatkan model peramalan nilai tukar rupiah terhadap dolar dengan Multiple Regression berdasarkan faktor faktor yang mempengaruhinya.

2. Untuk mengetahui ada tidaknya gangguan autokorelasi, multikolinieritas, dan heteroskedastisitas yang dialami model.

3. Untuk mengetahui error yang dihasilkan dari hasil peramalan multiple regression.

\section{Landasan Teori}

Kurs

Perdagangan internasional akan mendorong terjadinya pertukaran dua atau lebih mata uang berbeda. Transaksi ini akan menimbulkan permintaan dan penawaran terhadap suatu mata uang tertentu. Pada dasarnya, permintaan dan penawaran suatu mata uang tertentu akan mem-pengaruhi nilai tukar dari mata uang yang ber-sangkutan. Menurut Joesoef (2008:24) dalam Rohmanda (2014) "kurs (ex-change rate) adalah jumlah mata uang tertentu yang dapat ditukar terhadap satu unit mata uang lain".

Nilai tukar biasanya berubah-ubah, perubahan kurs dapat berupa depresiasi dan apresiasi. Depresiasi mata uang rupiah terhadap dolar AS (Amerika Serikat) artinya suatu penurunan harga dollar AS terhadap rupiah.Depresiasi mata uang negara membuat harga barang-barang domestik menjadi lebih murah bagi pihak luar negeri.Sedang apresiasi rupiah terhadap dollar AS adalah kenaikan rupiah terhadap dollar AS.Apresiasi mata uang suatu negara membuat harga barang barang domestik menjadi lebih mahal bagi fihak luar negeri (Sukirno, 1981:297 dalam Triyono, 2008).

\section{Faktor Faktor yang Mempengaruhi Kurs}

Ada beberapa faktor yang mempengaruhi kurs, diantaranya:

Berikut faktor yang mempengaruhi kurs secara langsung (Hady, 2004):

1. Dari sisi permintaan kurs valas dipengaruhi oleh:

a. Pembayaran impor

Semakin besar impor barang dan jasa akan semakin besar pula permintaan terhadap valuta asing yang digunakan dalam pembayaran impor, jika diasumsikan penawaran valuta asing di dalam negeri tetap maka nilai tukar akan cenderung melemah (terdepresiasi) terhadap mata uang asing.

b. Aliran modal keluar

Semakin besar aliran modal keluar maka akan semakin permintaan terhadap valuta asing akan meningkat sehingga nilai tukar domestik melemah (terdepresiasi) sebaliknya bila aliran modal yang keluar sedikit maka permintaan terhadap valas juga akan cenderung berkurang sehingga nilai tukar akan terapresiasi.

2. Dari sisi penawaran kurs valas dipengaruhi oleh:

a. Penerimaan hasil ekspor

Jika penerimaan hasil ekspor suatu negara meningkat, maka cadangan devisa negara yang dinilai dalam bentuk valuta asing akan meningkat, peningkatan ini akan menambah supply valas dimiliki suatu negara sehingga supply valas akan meningkat, akibatnya posisi nilai tukar domestik terhadap mata uang asing akan semakin menguat (terapresiasi).

b. Aliran modal masuk

Semakin deras aliran modal yang masuk kedalam negeri maka akan terjadi peningkatan pada supply valas, sehingga nilai tukar domestik akan cenderung menguat (terapresiasi) dan harganya relatif mahal terhadap mata uang asing. Sedangkan jika aliran modal yang masuk sedikit maka jumlah valuta asing yang masuk juga akan sedikit sehingga nilai tukar akan mengalami depresiasi.

Sedangkan secara tidak langsung, kurs valuta asing dipengaruhi oleh (Hady, 2004):

1. Inflasi

Kenaikan inflasi yang mendadak dan besar disuatu negara akan meningkatkan impor dinegara tersebut, hal ini terjadi karena harga barang domestik secara umum lebih mahal dibanding dengan harga barang luar negeri 
akibatnya dorongan masyarakat untuk membeli produksi luar negeri meningkat sehingga kebutuhan terhadap penggunaan mata uang asing menjadi lebih banyak, permintaan valas untuk membiayai impor akan naik.

2. Suku Bunga

Ketika suku bunga dalam negeri meningkat sementara suku bunga luar negeri tetap, maka minat investor untuk menanamkan modalnya didalam negeri semakin tinggi karena return yang didapat juga diharapkan akan lebih tinggi sehingga arus modal masuk akan meningkat. Permintaan terhadap mata uang domestik meningkat sehingga akan direspon dengan menguatnya mata uang dalam negeri.

3. Posisi Balance of Trade (BOT) dan Balance of Payment (BOP)

BOP surplus mencerminkan adanya aliran valuta asing yang masuk dalam perekonomian negara tersebut baik melalui transaksi barang dan jasa maupun asset, sehingga menyebabkan bertambahnya valuta asing dinegara tersebut dan mengakibatkan terjadinya apresiasi mata uang domestik terhadap mata uang asing.

4. Tingkat Income

Income suatu negara dapat dilihat dari Produk Domestik Bruto, jika meningkat maka permintaan terhadap mata uang domestik akan semakin meningkat. Dengan deikian nilai tukar mengalami apresiasi karena masyarakat lebih memilih untuk menggunakan mata uang domestik.

5. Peraturan dan Kebijakan Pemerintah Apabila peraturan atau kebijakan pemerintah yang dibuat menghambat atau mempersulit aliran modal yang masuk kedalam negeri maka akan terjadi depresiasi nilai tukar karena valuta asing yang masuk menurun.

\section{Spekulasi}

Spekulasi valas oleh para spekulan untuk mendapatkan keuntungan akan menyebabkan semakin meningkatnya permintaan terhadap valuta asing sehingga melemahkan nilai tukar domestik terhadap valuta asing.

7. Politik dan Keamanan

Jika politik dan keamanan dalam negeri tidak stabil akan menyebabkan banyaknya modal yang dilarikan keluar negeri sehingga akan terjadi tekanan pada nilai tukar dalam negeri yaitu terjadinya depresiasi nilai tukar.

\section{Multiple Regression}

Dalam upaya untuk meramalkan data dengan lebih dari satu variabel independent secara akurat, regresi linear sederhana tidak dapat diandalkan. Regresi linear sederhana masih tetap bisa. Analisis regresi pada dasarnya adalah studi mengenai ketergantungan variabel dependen (terikat) dengan satu atau lebih variabel independent (variabel penjelas/bebas), dengan tujuan untuk mengestimasi dan/atau memprediksi rata-rata populasi atau nilai nilai variabel dependen berdasarkan nilai variabel independent yang diketahui (Makridakis dkk, 1989)

Persamaan regresi linear berganda secara matematis dituliskan sebagai berikut:

$$
\begin{aligned}
& Y=a+b_{1} X_{1}+b_{2} X_{2}+b_{3} X_{3}+\ldots+b_{n} X_{n}+e \\
& \text { Dimana: } \\
& Y \quad=\text { variabel dependent } \\
& X_{n} \quad=\text { variabel independent } \\
& a \quad=\text { konstanta } \\
& b_{n} \quad=\text { konstanta variabel independent } \\
& e \quad=\text { error }
\end{aligned}
$$

\section{Metodologi Penelitian}

Berikut Gambar 1 yang merupakana flowchart penelitian: 


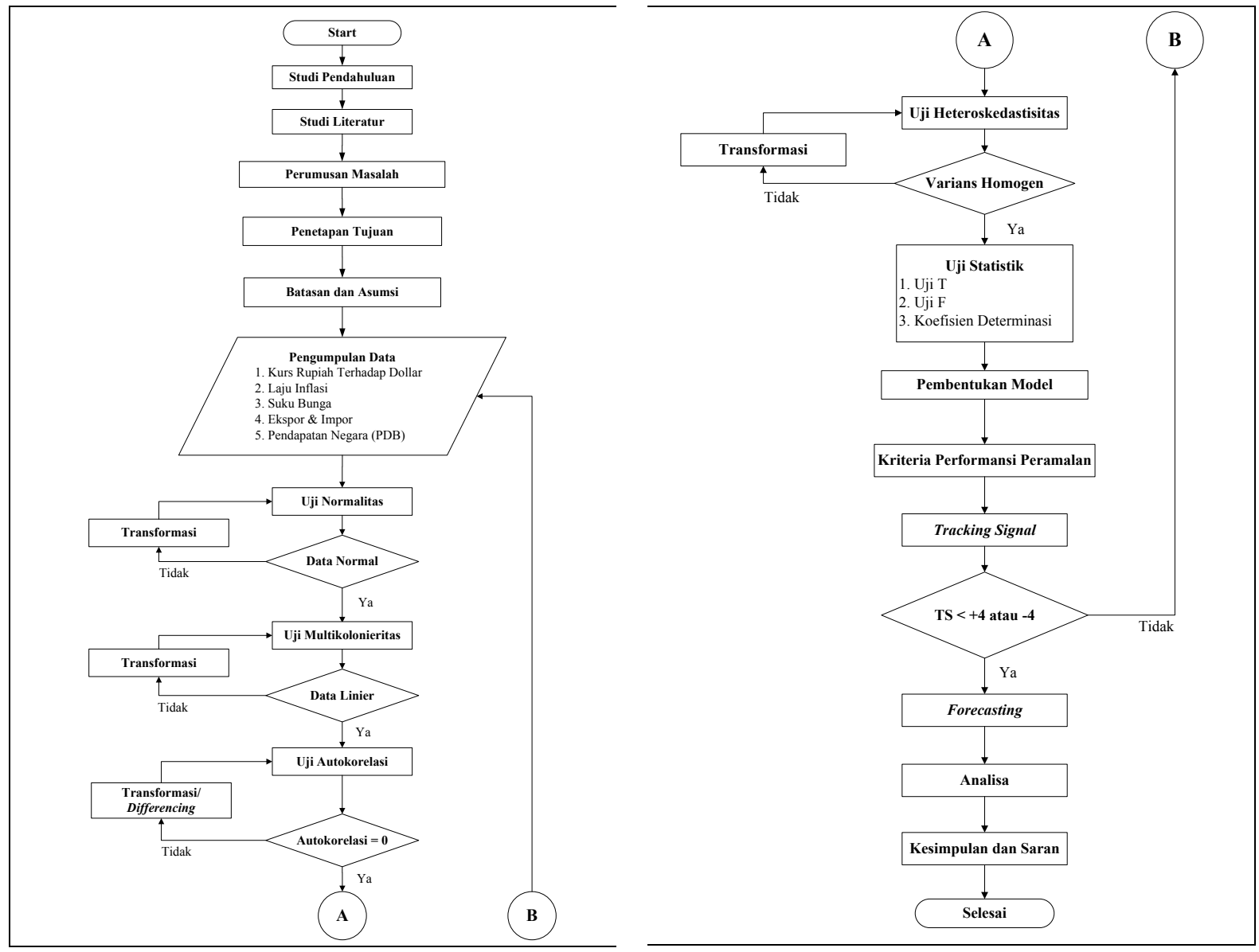

Gambar 1 Flowchart Metodologi Penelitian

Langkah pertama yang dilakukan dalam penelitian ini adalah mencari informasi mengenai forecasting dan kurs. Hal ini dilakukan untuk mendapatkan landasan yang kuat sekaligus untuk mencari permasalahan yang ditimbulkan oleh kurs lalu merumuskannya. Faktor faktor yang berpengaruh terhadap kurs juga dicari pada proses studi literatur dan perumusan masalah sebelum akhirnya mendapatkan komposisi yang sesuai untuk membentuk model multiple regression untuk memprediksi nilai kurs rupiah terhadap dolar dengan memasukkan variabel inflasi, suku bunga, ekspor, impor dan pendapatan negara sebagai acuannya.

Langkah selanjutnya adalah melakukan pengumpulan data data, seperti kurs, inflasi, suku bunga, ekspor, impor dan pendapatan negara. Data kurs rupiah, ekspor dan impor diperoleh dari website Kementrian Perdagangan (Kemendag.go.id), laju inflasi dan suku bunga diperoleh dari website Bank Indonesia (BI.go.id) dan pendapatan negara diperoleh dari website Balai Pusat Statistik (BPS.go.id). data juli 2016.
Data yang telah dikumpulkan diuji terlebih dahulu dengan uji asumsi klasik, yang terdiri dari uji normalitas untuk melihat kenormalan residual data, uji multikolinieritas untuk melihat ada tidaknya korelasi yang kuat antar variabel bebas, uji autokorelasi untuk melihat ada tidaknya korelasi antara data pada periode sekarang dengan data pada periode sebelumnya pada variabel yang sama, dan uji heteroskedastisitas untuk melihat ada tidaknya korelasi yang kuat antar varian dari tiap tiap variabel. Variabel yang tidak lolos uji akan melalui proses transformasi untuk mengubah bentuk data. jika memang tidak memungkinkan untuk dilakukan transformasi, maka data tersebut akan dibuang.

Setelah itu korelasi antar variabel baik secara individual maupun simultan diuji dengan menggunakan uji $\mathrm{T}$ dan uji $\mathrm{F}$ yang kemudian dilanjutkan dengan representasi nilai determinan $\left(\mathrm{R}^{2}\right)$. kemudian proses pembentukan model yang dilanjutkan dengan perhitungan error dan tracking signal untuk melihat kecocokan model dalam merepresentasikan data dan variabel. Langkah terakhir pada pengolahan data adalah melakukan forecasting untuk periode yang akan datang dengan menggunakan model. Terakhir penelitian ini ditutup dengan analisa, kesimpulan dan saran. 


\section{Hasil dan Pembahasan}

\section{Hasil}

Berikut hasil dari pengolahan data:

\section{Uji Asumsi Klasik}

Berdasarkan uji normalitas didapatkan hasil Asymp.sig (2-tailed) sebesar 0,93 dimana nilai ini lebih besar dari nilai $\alpha$ yaitu 0,05 . Oleh karena itu dapat diambil kesimpulan bahwa data pada penelitian ini normal.

Berdasarkan uji multikolinieritas, diketahui bahwa nilai tolerance masing masing variabel lebih besar dari 0,10 (tolerance $>0,10$ ) dan nilai VIF lebih kecil dari 10 (VIF $<10)$ sehingga dapat dinyatakan bahwa semua variabel bebas terhindar dari masalah multikolinieritas.

Uji autokorelasi menggunakan metode Durbin-Watson sebagai parameter. Dari hasil uji autokorelasi, didapatkan hasil:

$\mathrm{dL}=0,243$ (Tabel Durbin-Watson, $\mathrm{n}=10, \alpha=$ $0,05, \mathrm{k}=5)$

$\mathrm{dU}=2,822$ (Tabel Durbin-Watson, $\mathrm{n}=10, \alpha=$ $0,05, \mathrm{k}=5)$

$\mathrm{DW}=1,939 \quad(4-\mathrm{dU})=4-2,822=1,178$

karena DW terletak diantara dU dan (4$\mathrm{Du})$ atau dapat dituliskan:

$$
(4-\mathrm{dU})<\mathrm{DW}<\mathrm{dU}=(1,178<1,939<
$$

maka DW masuk ke dalam ketentuan 2, yaitu tidak terjadi autokorelasi.

Terakhir adalah uji heteroskedastisitas Berdasarkangunan metode glejser didapatkan nilai Sig Masing masing variabel lebih besar dari 0,05 yang berarti bahwa semua variabel tidak mengandung unsur heteroskedastisitas.

\section{Uji Statistik}

Uji statistik yang pertama dilakukan adalah uji $\mathrm{T}$ untuk melihat korelasi antara masing masing variabel independen (inflasi, suku bunga, ekspor, impor, dan pendapatan negara) terhadap variabel dependen (kurs). Dengan hipotesis "jika $\mathrm{T}_{\text {hitung }}$ lebih besar $(>)$ dari $\mathrm{T}_{\text {tabel }}$ maka terima $\mathrm{H} 1$ atau berarti bahwa variabel independen tidak berpengaruh signifikan terhadap variabel dependen, didapatkan hasil:

Tabel 1Output Uji T
\begin{tabular}{|l|c|c|l|}
\hline \multicolumn{1}{|c|}{ Model } & \multicolumn{1}{c|}{ T } & Sig. & \multicolumn{1}{c|}{ Keterangan } \\
\hline (Constant) & 2.666 & .056 & \\
\hline Inflasi & 1.508 & .206 & Tidak berpengaruh \\
\hline Suku Bunga & 2.774 & .050 & berpengaruh \\
\hline
\end{tabular}

\begin{tabular}{|l|r|r|l|}
\hline Ekspor & -1.202 & .296 & Tidak berpengaruh \\
\hline Impor & -.386 & .719 & Tidak berpengaruh \\
\hline GDP & .569 & .600 & Tidak berpengaruh \\
\hline
\end{tabular}

Selanjutnya uji $\mathrm{F}$ untuk melihat pengaruh variabel independen terhadap variabel dependen secara simultan atau bersama sama. Dengan menggunakan hipotesis "jika $F_{\text {hitung }}$ lebih besar $(>)$ dari $\mathrm{F}_{\text {tabel }}$ maka terima $\mathrm{H} 1$ atau berarti bahwa variabel independen tidak berpengaruh signifikan terhadap variabel dependen, didapatkan hasil:

$$
\begin{array}{llll}
\mathrm{F}_{\text {Hitung }}=7,828 & & \\
\mathrm{df}_{1}=\mathrm{k}-1 & =5-1 & =4 \\
\mathrm{df}_{2} \quad=\mathrm{n}-\mathrm{k} & =10-5 & =5 \\
\mathrm{~F}_{\text {Tabel }(0,95 ; 4 ; 5)} & & =5,19
\end{array}
$$

$\mathrm{F}_{\text {Hitung }}>\mathrm{F}_{\text {Tabel, }}$, maka $\mathrm{H}_{1}$ diterima dan $\mathrm{H}_{0}$ ditolak, yang berarti ada pengaruh yang signifikan dari laju inflasi, suku bunga, ekspor, impor dan pendapatan negara terhadap kurs.

Terakhir pada uji statistik dilakukan representasi determinan $\left(\mathrm{R}^{2}\right)$. Berikut hasil dari representasi determinan:

Tabel 2 Representasi Determinan

\begin{tabular}{|l|l|r|r|}
\hline Model & \multicolumn{1}{|c|}{$\mathbf{R}$} & R Square & $\begin{array}{c}\text { Adjusted } \boldsymbol{R} \\
\text { Square }\end{array}$ \\
\hline 1 & $.953^{\mathrm{a}}$ & .907 & .791 \\
\hline
\end{tabular}

Hasil di atas menunjukkan nilai $\mathrm{R}^{2}$ mendekati angka 1, yaitu sebesar 0,907.Hal ini berarti variabel variabel independen mampu menginterpretasikan variabel dependen dengan sangat baik. Pada periode penelitian ini secara statistik sebanyak $90,7 \%$ pergerakan nilai kurs dipengaruhi oleh laju inflasi, suku bunga, ekspor, impor dan pendapatan negara sedangkan 9,3\% dipengaruhi oleh faktor faktor lainnya.

\section{Pembentukan Model}

Setelah melakukan uji asumsi klasik diketahui bahwa semua variabel indenpenden yaitu inflasi, suku bunga, ekspor, impor dan pendapatan negara tidak mengalami gangguan dari segi kenormalan, multikolinieritas, autokorelasi dan heteroskedastisitas. Berdasarkan pengolahan data menggunakan SPSS, didapatkan model regresi linear berganda sebagai berikut:

$$
\begin{aligned}
& \mathrm{Y}=10.069,111+252,064 \times \text { Inflasi }+ \\
& 571,387 \times \text { Suku Bunga }-0,140 \times \mathrm{x} \\
& \text { Ekspor }-0,059 \times \text { Impor }+0,002 \times \\
& \text { Pendapatan Negara) }
\end{aligned}
$$

\section{Kriteria Performansi}

Kriteria Performansi Peramalan (KPP) biasa dikenal dengan perhitungan error. KPP 
diolah dengan menggunakan software QM untuk menghitung nilai mean absolute deviation (MAD) dan mean absolute percentage error (MAPE). Berikut hasil dari perhitungan KPP:

\begin{tabular}{l}
\hline Pat. Forecasting Results \\
\begin{tabular}{|l|r|}
\hline \multicolumn{2}{|c|}{ Prediksi Nilai Kurs Rupiah terhadap Dolar Summary } \\
\hline Measure & Value \\
\hline Error Measures & 0 \\
\hline Bias (Mean Error) & 66,996 \\
\hline MAD (Mean Absolute Deviation) & 7135,749 \\
\hline MSE (Mean Squared Error) & 133,564 \\
\hline Standard Error (denom=n-2-4=4) &, 005 \\
\hline MAPE (Mean Absolute Percent Error) & \\
\hline
\end{tabular}
\end{tabular}

Gambar 2 Kriteria Performansi Peramalan

Dari Gambar 2 diperoleh nilai MAD sebesar 66,996 dan MAPE sebesar 0,005 atau $0,5 \%$.

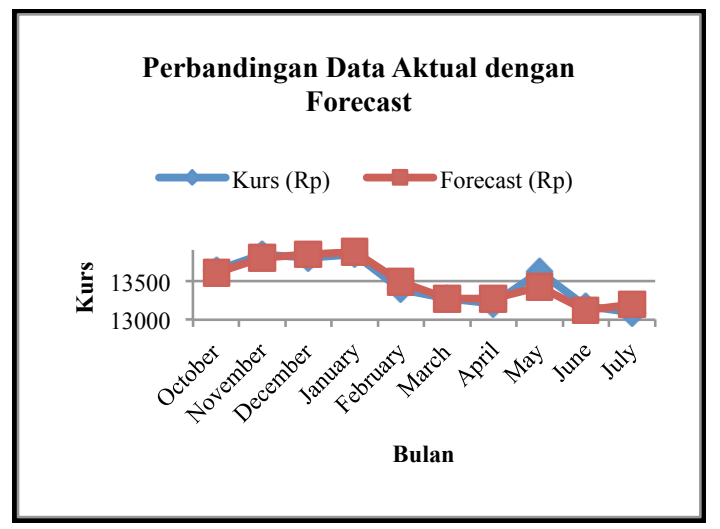

Gambar 3 Grafik Perbandingan Data Aktual dengan

\section{Tracking Signal} Forecast

Dari hasil tracking signal menunjukkan bahwa model tidak terdapat periode data yang melewati batas $(-4$ atau +4$)$. Hal ini berarti model multiple regression ini valid dan dapat digunakan dalam peramalan nilai kurs rupiah terhadap dolar.

\section{Forecasting}

Sebelum melakukan prediksi nilai kurs rupiah pada periode yang akan datang, terlebih dahulu dilakukan prediksi terhadap nilail nilai dari masing masing variabel independen. Berikut hasil prediksi nilai variabel independen dengan menggunakan metode decomposition:

Tabel 2 Prediksi Variabel Independen
\begin{tabular}{|l|r|r|r|}
\hline Bulan & Agustus & \multicolumn{1}{c|}{ September } & Oktober \\
\hline Inflasi (\%) & 0,351 & 0,465 & 0,392 \\
\hline Suku Bunga & 6,117 & 6,116 & 6,084 \\
\hline
\end{tabular}

\begin{tabular}{|l|r|r|r|}
\hline (\%) & & & \\
\hline $\begin{array}{l}\text { Ekspor } \\
\text { (Juta US\$) }\end{array}$ & 12101,7 & 13058,98 & 12188,39 \\
\hline $\begin{array}{l}\text { Impor (Juta } \\
\text { US\$) }\end{array}$ & 11617,3 & 12404,4 & 11668,17 \\
\hline $\begin{array}{l}\text { PDB } \\
\text { (Milyar } \\
\text { Rupiah) }\end{array}$ & 1054490 & 1054082 & 1080748 \\
\hline
\end{tabular}

Berdasarkan forecasting data input yang telah dilakukan di atas, maka langkah terakhir adalah melakukan forecast untuk nilai kurs pada 3 periode ke depan dengan menggunakan Rumus 4.1 .

Kurs $_{\text {Agustus }}$

$$
\begin{aligned}
= & 10.069,11+(252,064 \times 0,351)+(571,387 \\
& \quad \text { } 6,117)-(0,14 \times 12101,75)-(0,059 \times \\
& 11617,34)+(0,002 \times 1054490) \\
= & 10.069,11+88,474+3495,174-1694,25 \\
& -685,42+2108,98 \\
= & \text { Rp 13.382,07 Per } 1 \text { US\$ }
\end{aligned}
$$

$$
\begin{aligned}
& \text { Kurs }_{\text {September }} \\
&= 10.069,11+(252,064 \times 0,465)+(571,387 \\
&\times 6,116)-(0,14 \times 13058,98)-(0,059 \times \\
&12404,4)+(0,002 \times 1054082) \\
&= 10.069,11+117,210+3184,603- \\
& 1828,26-731,86+2108,16 \\
&= \text { Rp } 13.228,97 \text { Per 1 US\$ }
\end{aligned}
$$

$$
\begin{aligned}
& \text { Kurs }_{\text {Oktober }} \\
& =10.069,11+(252,064 \times 0,392)+(571,387 \\
& \quad \times 6,084)-(0,14 \times 12188,39)-(0,059 \times \\
& \quad 11668,17)+(0,002 \times 1080748) \\
& =10.069,11+98,809+3476,319-1706,37 \\
& \quad-688,42+2161,50 \\
& =\quad \text { Rp 13.410,94 Per 1 US\$ }
\end{aligned}
$$

Dari hasil di atas terlihat rupiah mengalami pelemahan pada bulan agustus. Rupiah melemah 288,07 poin dibandingkan bulan juli dan membawa rupiah ke level Rp 13.382,07 per 1 US\$. Namun rupiah kembali menguat pada bulan september ke level Rp 13.228,97 atau naik 153,10 poin. Pada bulan oktober, rupiah kembali melemah 181,97 poin ke level Rp $13.410,94$ per 1 US\$.

\section{Pengumpulan Data}

\section{Pembahasan}

Bulan oktober 2015 digunakan sebagai acuan bulan dasar dalam forecasting ini. Hal ini dikarenakan pada periode diatas oktober 2015, nilai tukar rupiah terhadap dolar lebih stabil dibandingkan periode sebelumnya dimana pada periode sebelum oktober 2015 juga tidak 
ditemukan adanya fluktuasi yang tinggi pada data variabel independen sehingga dimungkinkan fluktuasi tersebut dikarenakan adanya spekulasi pasar dan kebijakan suku bunga bank sentral Amerika, The Fed.

\section{Uji Asumsi Klasik}

Pada 4 uji asumsi klasik, yaitu uji normalitas, multikolinieritas, autokorelasi, dan heteroskedastisitas tidak ditemukan adanya gangguan yang berarti. Tercatat hanya pada uji multikolinieritas dimana variabel impor yang memiliki indikasi mengalami ganggu pada data. Hal ini terlihat dari output nya mendekati batas batas dari uji multikolinieritas. Tetapi secara keseluruhan tidak ditemukan adanya gangguan.

Dengan tidak adanya gangguan pada data maka akan membuat selisih antara kurs yang dihasilkan dari model dengan kurs asli akan semakin kecil atau dalam bahasa lain tingkat error akan semakin kecil.

\section{Uji Statistik}

Pada uji T diketahui bahwa hanya ada satu variabel yang berpengaruh signifikan positif, yaitu suku bunga, sedangkan variabel lain tidak berpengaruh. Dengan adanya hasil ini maka dapat dimungkin kan untuk mengambil keputusan menghilangkan variabel lainnya. Tetapi hasil ini bukanlah menjadi acuan mutlak karena masih terdapat uji lainnya.

Pada uji F didapatkan hasil bahwa variabel independen secara simultan mempengaruhi variabel dependen. Hasil uji F bisa menjadi acuan dalam menjawab keraguan pada uji $\mathrm{T}$, karena pada dasarnya penelitian ini dilakukan untuk mencari hubungan antara keseluruhan variabel independen terhadap variabel dependen yang akhirnya akan didapatkan model dari hubungan ini.

Secara bahasa, variabel variabel indenden membangun model secara bersama sama, tidak dalam substansi individual, sehingga walaupun secara individual salah satu variabel tidak berpengaruh, tetapi secara simultan mereka dapat berpengaruh.

Hasil dari uji $\mathrm{F}$ juga diperkuat dengan hasil pada koefisien determinasi. Variabel independen pada penelitian ini memberikan kontribusi 90,7\% untuk membentuk nilai kurs rupiah terhadap dolar, sedangkan 9,35 lainnya didapatkan dari variabel lainnya. hasil ini membuktikan teori bahwa variabel inflasi, suku bunga, ekspor, impor dan pendapatan negara berpengaruh terhadap kurs rupiah.

\section{Pembentukan Model}

Inflasi mendapatkan nilai $+252,064$. Hasil ini sesuai dengan teori naiknya inflasi akan membuat mata uang melemah. Inflasi dapat menyebabkan jumlah uang yang beredar meningkat karena untuk membeli suatu barang dibutuhkan uang yang lebih banyak.Hal ini dapat menyebabkan pelemahan nilai rupiah sehingga memberi efek domino pada nilai tukar terhadap dolar.

Naiknya inflasi akan mendorong pelaku pasar untuk mencari alternatif produk yang sama dengan harga yang lebih murah. Jalan terbaik adalah dengan melakukan impor barang yang berakibat penawaran akan rupiah menjadi tinggi dan permintaan dolar menguat sehingga posisi rupiah akan semakin melemah.

Suku bunga mendapatkan nilai $+571,387$ yang artinya ketika suku bunga naik maka rupiah akan melemah. Suku bunga termasuk ke dalam variabel yang cukup unik.Pengaruhnya bisa positif ataupun negatif, yaitu dapat menguatkan ataupun melemahkan kurs.Suku bunga yang tinggi dapat menarik minat investor asing untuk berinvestasi.Tetapi pada negara berkembang, suku bunga yang tinggi tidak disukai oleh pemilik perusahaan. Dengan suku bunga yang tinggi biaya modal akan menjadi lebih besar, begitu juga dengan return yang dijanjikan kepada investor yang akan semakin tinggi sehingga menyebabkan kelesuan industri (Kewal, 2012). Hal ini dapat mengurangi minat investor asing.

Naiknya suku bunga akan mengurangi daya beli masyarakat. Pengajuan kredit akan menjadi lebih sedikit sehingga investor asing memilih untuk berinvestasi di negara lain.

Ekspor mendapatkan nilai default -0,14, yang artinya semakin tinggi ekspor, maka rupiah akan menguat. Hasil ini sesuai dengan teori hubungan antara ekspor dan kurs. Dalam melakukan ekspor, produsen (ataupun distributor) akan mendapatkan bayaran dalam bentuk mata uang asing, dolar. Untuk menjaga kelangsungan perusahaan, mereka menukarkan dolar yang didapat dengan rupiah untuk keperluan membeli bahan baku, membayar karyawan dan lain lain. Naiknya permintaan rupiah dan naiknya penawaran dolar akan menguatkan posisi rupiah sekaligus melemahkan rupiah.

Hasil yang tidak sesuai teori didapatkan oleh impor yang mendapatkan nilai $-0,059$. Secara teori, impor akan menyebabkan penawaran rupiah menjadi tinggi karena pelaku pasar membutuhkan dolar untuk membayar produk yang mereka beli. 
Tetapi pada model, naiknya impor akan membuat rupiah semakin menguat.

Hasil ini bisa disebabkan karena pada ekspor dan impor dalam biasanya disatukan dalam suatu laporan neraca perdagangan, dimana laporan ini juga mencakup aliran modal. Seperti yang dikutip dari berita harian Kementrian Keuangan (Kemenkeu.go.id, 2016) dimana neraca perdagangan Indonesia pada bulan juni 2016 surplus US $\$ 0,88$ milyar dan juli sebesar US $\$ 0,6$ milyar. Neraca perdagangan yang surplus dapat merangsang rupiah untuk menguat, akibatnya besaran impor tidak berpengaruh terhadap nilai kurs karena kurs semakin kuat sehingga interpretasi impor terhadap model menjadi terganggu.

Pendapatan negara termasuk salah satu variabel yang berbanding terbalik dengan teori. Pendapatan negara mendapatkan nilai $+0,002$, yang artinya naiknya pendapatan negara justru akan memperlemah rupiah. Hal ini disebabkan karena utang luar negri dan bunga yang harus dibayarkan Indonesia cukup tinggi, sehingga pendapatan negara tidak menolong penguatan rupiah. Tercatat utang luar negeri Indonesia pada agustus 2016 mencapai Rp3.359,52 triliun (Okezone.com, 2016).

Kondisi ini diperparah dengan defisit Anggaran Penerimaan dan Belanja Negara (APBN) 2016 sebesar Rp296,723 triliun (Detik.com, 2016). Untuk menutupi defisit anggaran, pemerintah akan menerbitkan Surat Utang Negara (SUN) untuk mendapatkan utang sebesar Rp365,729 trilun.

Kombinasi antara defisit anggaran dan juga utang yang semakin banyak akan menyebabkan bias pada pengaruh pendapatan negara terhadap nilai tukar rupiah, sehingga naiknya pendapatan negara secara langsung tidak berpengaruh pada kurs.

\section{Kriteria Performansi Peramalan (KPP)}

Berdasarkan perhitungan KPP, error yang dihasilkan cukup rendah. Rata rata simpangan yang dihasilkan dari model ini hanya 66,996 poin per periodenya, atau $0,005 \%$. Model ini dinilai cukup baik dalam menginterpretasikan nilai rupiah pada periode oktober 2015 sampai juli 2016.

\section{Forecasting}

Pada agustus 2016, berdasarkan data Bank Indonesia (BI) kurs referensi rupiah terhadap dolar berada pada angka Rp13.165 per dolar. Angka ini menghasilkan selisih 217 poin dengan data ramalan yang berada pada $\mathrm{Rp} 13.382,07$ per dolar. Pada bulan september 2016, hasil peramalan menunjukkan nilai yang lebih baik dimana nilai aktual berada pada Rp13.145 per dolar sedangkan data ramalan menghasilkan angka Rp13.228,97 per dolar yang memiliki selisih 84 poin.

Selisih yang cukup besar ini dikarenakan ada beberapa faktor penting yang menguatkan rupiah.Pertama kebijakan tax amnesty (pengampunan pajak) yang mendorong para pelaku bisnis untuk melaporkan pajak mereka kepada negara tanpa dikenai sanksi apapun jika terdapat kecurangan pajak pada periode sebelumnya. Berdasarkan berita harian detik (Detik.com, 2016) yang dikutip dari data statistik tax amnesty Direktorat Jendral Pajak, hingga tanggal 26 september 2016, total deklarasi harta sudah mencapai Rp1.939 triliun atau mendekati target Rp2.000 triliun. Sebanyak Rp1.315 triliun merupakan harta dalam negri sedangkan Rp526 triliun berasal dari luar negri dimana sebanyak Rp98,7 triliun direpatriasi atau dibawa kembali ke Indonesia.

Kedua kembalinya Sri Mulyani sebagai Menteri Perekonomian juga mendorong keyakinan publik terhadap perekonomian Indonesia.Kehadiran Sri Mulyani meyakinkan para investor untuk berinvestasi di Indonesia mengingat kemampuan Sri Mulyani dalam menstabilkan keuangan Indonesia.

Faktor lain yang ikut membantu adalah penggunaan BI 7 Day Reverse Repo Rate yang menggantikan BI Rate dimana pada pembukaannya, BI menetapkan suku bunga sebesar 5,25\%. Suku bunga yang rendah diharap dapat merangsang pertumbuhan ekonomi dan juga meningkatkan minat dari investor.

Namun perlu diingat bahwa banyak faktor faktor eksternal yang dapat menguatkan ataupun menjatuhkan nilai rupiah dalam waktu yang singkat.Salah satunya adalah kebijakan suku bunga The Fed. Pertumbuhan ekonomi yang baik akan membuat mata uang Indonesia lebih kuat lagi sehingga pengaruh dari perubahan suku bunga The Fed tidak menimbulkan dampak yang besar bagi Indonesia.

\section{Kesimpulan}

Dari pengolahan data yang telah dilakukan maka dapat diambil kesimpulan sebagai berikut:

1. Model peramalaan multiple regression untuk memprediksi kurs rupiah terhadap dolar dengan pertimbangan faktor inflasi, suku bunga, ekspor, impor dan pendapatan negara dalam penelitian ini dirumuskan dengan persamaan: 
$\mathrm{Y}=10.069,111+252,064 \mathrm{x}$ Inflasi + 571,387 x Suku Bunga - 0,140 x Ekspor 0,059 x Impor $+0,002 \times$ Pendapatan Negara Dari model di atas didapatkan nilai kurs rupiah terhadap dolar pada bulan juli seharga Rp 13.382,07 per 1 US\$, bulan september sebesar Rp 13.228,97 dan bulan oktober sebesar Rp 13.410,94 per 1 US\$.

2. Pada uji asumsi klasik ditemukan adanya potensi gangguan pada uji multikolinieritas, tetapi gangguan tersebut tidak memberikan pengaruh yang signifikan terhadap model karena pada keseluruhan uji asumsi klasik tidak ditemukan adanya gangguan pada model.

3. Berdasarkan model 4.1 diperoleh nilai MAD (Mean Absolute Deviation) sebesar 66,996 dan MAPE (Mean Absolute Percentage Error) sebesar 0,005 atau $0,5 \%$.

\section{Daftar Pustaka}

Ajeng, Sri. "Peramalan Penjualan untuk Perencanaan Pengadaan Persediaan Buah Durian di Rumah Durian Harum Bintaro, Jakarta".Skripsi Universitas Islam Negri Syarif Hidayatullah, Jakarta. 2011. [Online] Available: http://repository.uinjkt.ac.id/, diakses 12 Mei 2016.

Boediono, dan Wayan Koster. "Teori dan Aplikasi: Statistika dan Probabilitas". PT Remaja Rosdakarya, Bandung. 2008.

Fajriasari, Ana. "Pengaruh Jumlah Wisatawan, Lama Tinggal, Dan Pegeluarannya Terhadap Produk Regional Bruto Sektor Pariwisata Jawa Tengah". Skripsi Universitas Pendidikan Indonesia, Bogor. 2013. [Online] Available: http://repository.upi.edu/, diakses 12 Mei 2016.

Gaspersz, Vincent. "Production Planning and Inventory Control". Gramedia Pustaka Utama, Jakarta. 1998.

Gujarati, Damodar N. " Basic Econometric, Fourth Edition". New York: McGraw Hill, New York. 2003

Hady, Hamdy. "Ekonomi Internasional: Teori dan Kebijakan Keuangan Internasional". Ghalia Indonesia, Jakarta. 2004.

Hasanah, Uswatun. "Analisis Hubungan Cuaca dan Jmlah Penderita Demam Berdarah Dengue (DBD) Dengan Fungsi Transfer". Skripsi Institut Pertanian Bogor, Bogor. 2007. [Online] Available: http://repository.ipb.ac.id/, diakses 12 Mei 2016.

Kewal, Saramaya Suci. "Pengaruh Inflasi, Suku Bunga, Kurs dan Pertumbuhan PDB terhadap Indeks Harga Saham Gabungan”. Jurnal Economia, Volume 8, Nomor 1, April 2012. Sekolah Tinggi Ilmu Ekonomi Musi, Palembang. 2012. [Online] Available:

http://download.portalgaruda.org/, diakses 12 Mei 2016.

Krisnilasari, Monica. "Analisis Pengaruh Likuiditas Obligasi, Coupon Dan Jangka Waktu Jatuh Tempo Obligasi Terhadap Perubahan Harga Obligasi Di Bursa Efek Surabaya".Tesis Universitas Diponegoro, Semarang. 2007. [Online] Available: http://eprints.undip.ac.id/, diakses $12 \mathrm{Mei}$ 2016.

Lind, Douglas A., William G. Marchall, dan Samuel A. Wathen. "Teknik Teknik Statistikan dalam Bisnis dan Ekonomi".'Buku 2, Edisi ke 15. Terjemahan Romi Bakti Hartanto. Salemba Empat, Jakarta. 2014.

Makridakis, Spyros, dan Steven G. Wheelwright. "Forecasting Methods for Management". John Wiley \& Sons, Inc, Singapore. 1989.

Pratiwi, Tara Eka. "Analisis Perilaku Kurs Rupiah (IDR) Terhadap Dollar Amerika (USD) Pada Sistem Kurs Mengambang Bebas Di Indonesia Periode 1997.3 2011.4”. Skripsi Universitas Diponegoro Semarang, Semarang. 2012. [Online] Available: http://eprints.undip.ac.id/, diakses 12 Mei 2016.

Rohmanda Deny, Suhadak, Topowijono. "Pengaruh Kurs Rupiah, Inflasi Dan Bi Rate Terhadap Harga Saham”. Jurnal Administrasi Bisnis (Jab), Vol. 13, No. 1, Agustus 2014, Universitas Brawijaya, Malang. 2014. [Online] Available: http://administrasibisnis.studentjournal.ub.ac .id/, diakses 13 Mei 2016.

Sayyida."Pengaruh biaya produksi terhadap laba perumahan".Jurnal "PERFORMANCE" Bisnis dan Akuntansi, Vol. IV No.1, Maret 2014. Universitas Wirajaya, Sumenep. 2014. [Online] Available; http://download.portalgaruda.org/, diakses 12 Mei 2016.

Sukirno, Sadono. "Makroekonomi: Teori Pengantar”. Edisi ke 3. Rajawali Press, Jakarta. 2010 
Supranto, Johannes. "Metode Riset dan Aplikasinya dalam Pemasaran”.Rineka Cipta, Jakarta. 2004.

Sutrisni."Analisis Pengaruh Kualitas Produk, Kualitas Pelayanan, Desain Produk, Harga Dan Kepercayaan Terhadap Loyalitas Pelanggan Indosat Im3 Pada Mahasiswa Fakultas Ekonomi Universitas Diponegoro Semarang”. Skripsi Universitas Diponegoro, Semarang. 2010. [Online] Available: http://eprints.ums.ac.id/, diakses 14 Mei 2016.

Triyono."Analisis Perubahan Kurs Rupiah Terhadap Dollar Amerika”.Jurnal Ekonomi Pembangunan, Vol. 9, No. 2, Desember 2008, Hal. 156-157. Universitas Muhammadiyah Surakarta, Surakarta. 2008. [Online] Available: http://journals.ums.ac.id/index.php/, diakses 14 Mei 2016. 